\title{
Catalytic liquid phase oxidation of 1,4-dioxane over a $\mathrm{Pt} / \mathrm{CeO}_{2}-\mathrm{ZrO}_{2}-\mathrm{Bi}_{2} \mathrm{O}_{3} / \mathrm{SBA}-16$ catalyst
}

\author{
Pil-Gyu CHOI, Takanobu OHNO, Nashito FUKUHARA, \\ Toshiyuki MASUI, Nobuhito IMANAKA* \\ Department of Applied Chemistry, Faculty of Engineering, Osaka University, 2-1 Yamadaoka, Suita, \\ Osaka 565-0871, Japan
}

Received: August 20, 2014; Revised: October 29, 2014; Accepted: November 06, 2014

(C) The Author(s) 2015. This article is published with open access at Springerlink.com

\begin{abstract}
A Pt/CeO $2-\mathrm{ZrO}_{2}-\mathrm{Bi}_{2} \mathrm{O}_{3} / \mathrm{SBA}-16$ (Santa Barbara Amorphous No. 16) catalyst was prepared by hydrothermal and wet impregnation methods for catalytic purification of 1,4-dioxane in water. SBA-16 has a number of mesopores and the average size of the pores is $9.4 \mathrm{~nm}$. In the present catalyst, platinum and $\mathrm{CeO}_{2}-\mathrm{ZrO}_{2}-\mathrm{Bi}_{2} \mathrm{O}_{3}$ were successfully dispersed in the pores of the SBA-16 support, and the temperature dependence of the liquid phase oxidation of 1,4-dioxane was examined. The oxidation reaction proceeded effectively in the air atmosphere in the temperature range of 40 $80{ }^{\circ} \mathrm{C}$.
\end{abstract}

Keywords: composite materials; oxidation; porous materials; 1,4-dioxane; catalyst

\section{Introduction}

1,4-dioxane is a cyclic ether that possesses satisfactory solubility in water as well as organic solvents. It exists in its liquid state at ordinary temperature, and its boiling point is $101{ }^{\circ} \mathrm{C}$ [1] which is almost equivalent to that of water $\left(100{ }^{\circ} \mathrm{C}\right) .1,4$-dioxane has been used as a solvent for extraction, purification and chemical reaction [2-4], but it has been identified as a cancer-causing pollutant by animal testing [5]. Therefore, a stringent environmental quality standard for water pollution has been established for 1,4-dioxane: for example, it is $0.05 \mathrm{mg} / \mathrm{L}$ or below in Japan [6]. Unfortunately, however, 1,4-dioxane is a persistent substance not to be susceptible to hydrolysis and biodegradation [4,7]. Accordingly, it is significantly difficult to eliminate 1,4-dioxane with

* Corresponding author.

E-mail: imanaka@chem.eng.osaka-u.ac.jp microbial processes at wastewater treatment plants [8]. Furthermore, 1,4-dioxane is poorly adsorbed onto active carbon, and it is possible to be eliminated only in the presence of ozone by oxidation [9]. Therefore, an effective treatment process remains to be established, and it has been required to find a novel water treatment technology for degradation of 1,4-dioxane.

In this study, a porous catalyst was prepared for the degradation of 1,4-dioxane in water, where platinum and $\mathrm{CeO}_{2}-\mathrm{ZrO}_{2}-\mathrm{Bi}_{2} \mathrm{O}_{3}$ were dispersed in the pores of the SBA-16 (Santa Barbara Amorphous No. 16) support [10] which has pore size around $9.4 \mathrm{~nm}$ suitable for the insertion of platinum and $\mathrm{CeO}_{2}-\mathrm{ZrO}_{2}-\mathrm{Bi}_{2} \mathrm{O}_{3}$ particles. In the present catalyst, platinum works as a main oxidation catalyst and $\mathrm{CeO}_{2}-\mathrm{ZrO}_{2}-\mathrm{Bi}_{2} \mathrm{O}_{3}$ solid solution plays a promoter role to facilitate oxidation by supplying active oxygen from the inside bulk due to the oxygen storage and release properties [11-13]. When these components are 
supported inside the mesopores of SBA-16, it becomes possible to adsorb and decompose 1,4-dioxane at once. The reaction is carried out in air with vigorous stirring, and, thereby, the lattice oxygen of the $\mathrm{CeO}_{2}-\mathrm{ZrO}_{2}-\mathrm{Bi}_{2} \mathrm{O}_{3}$ promoter is continuously recovered by absorption of oxygen from the air through liquid water phase. In this study, therefore, catalytic purification performance of 1,4-dioxane in water was evaluated for the $\mathrm{Pt} / \mathrm{CeO}_{2}-\mathrm{ZrO}_{2}-\mathrm{Bi}_{2} \mathrm{O}_{3} / \mathrm{SBA}-16$ catalyst.

\section{Experimental procedure}

\section{1 Catalyst preparation}

SBA-16 was prepared according to the hydrothermal method described in previous studies [10,14]. Pluronic F-127 (1.6 g) and 1,3,5-trimethylbenzene $\left(1.1 \mathrm{~cm}^{3}\right)$ were dissolved into $0.2 \mathrm{~mol} / \mathrm{dm}^{3}$ hydrochloric acid $\left(90 \mathrm{~cm}^{3}\right)$, and the mixture was stirred at $35^{\circ} \mathrm{C}$ for $3 \mathrm{~h}$. After stirring, tetraethyl orthosilicate $\left(7.1 \mathrm{~cm}^{3}\right)$ was added to the solution, and the mixture was stirred again at $35{ }^{\circ} \mathrm{C}$ for $20 \mathrm{~h}$. Then the mixture was poured into a Teflon bottle in a sealed brass vessel and heated at $140{ }^{\circ} \mathrm{C}$ for $24 \mathrm{~h}$. The solid product was collected by filtration, washed and dried at room temperature for $12 \mathrm{~h}$. Finally, the dried powder was calcined at $600{ }^{\circ} \mathrm{C}$ for $4 \mathrm{~h}$ in air to obtain SBA-16.

Subsequently, $\mathrm{Ce}_{0.68} \mathrm{Zr}_{0.17} \mathrm{Bi}_{0.15} \mathrm{O}_{1.925}$ solid solution was supported on SBA-16 by an impregnation method. The SBA-16 support synthesized above $(0.40 \mathrm{~g})$ was dispersed into a stoichiometric mixture of $1.0 \mathrm{~mol} / \mathrm{dm}^{3}$ $\mathrm{Ce}\left(\mathrm{NO}_{3}\right)_{3} \quad\left(0.30 \mathrm{~cm}^{3}\right), \quad 0.1 \mathrm{~mol} / \mathrm{dm}^{3} \quad \mathrm{ZrO}\left(\mathrm{NO}_{3}\right)_{2}$ $\left(0.73 \mathrm{~cm}^{3}\right)$ and $0.5 \mathrm{~mol} / \mathrm{dm}^{3} \quad \mathrm{Bi}\left(\mathrm{NO}_{3}\right)_{3} \quad\left(0.13 \mathrm{~cm}^{3}\right)$ aqueous solutions. Then, $6.8 \times 10^{-2} \mathrm{~mol} / \mathrm{dm}^{3}$ nitric acid aqueous solution $\left(50 \mathrm{~cm}^{3}\right)$ was added, and the mixture was stirred at room temperature for $6 \mathrm{~h}$. The content of $\mathrm{Ce}_{0.68} \mathrm{Zr}_{0.17} \mathrm{Bi}_{0.15} \mathrm{O}_{1.925}$ was adjusted to be $16 \mathrm{wt} \%$, which was the optimum amount for toluene oxidation [15]. After stirring, the solvent was vaporized at $180{ }^{\circ} \mathrm{C}$. The powder obtained was ground in a mortar and calcined at $600{ }^{\circ} \mathrm{C}$ for $1 \mathrm{~h}$ in air.

Finally, platinum was dispersed on the $\mathrm{Ce}_{0.68} \mathrm{Zr}_{0.17} \mathrm{Bi}_{0.15} \mathrm{O}_{1.925} /$ SBA-16 powder using a platinum colloid stabilized with polyvinylpyrrolidone. The Pt content was adjusted to be $7 \mathrm{wt} \%$ for exactly the same reason as $\mathrm{Ce}_{0.68} \mathrm{Zr}_{0.17} \mathrm{Bi}_{0.15} \mathrm{O}_{1.925}$ mentioned above [15]. After the deposition, the solvent was evaporated at $180{ }^{\circ} \mathrm{C}$. The dried powder was ground in a mortar and calcined at $500{ }^{\circ} \mathrm{C}$ for $4 \mathrm{~h}$ in air to obtain a $\mathrm{Pt}(7 \mathrm{wt} \%) / \mathrm{Ce}_{0.68} \mathrm{Zr}_{0.17} \mathrm{Bi}_{0.15} \mathrm{O}_{1.925}(16 \mathrm{wt} \%) / \mathrm{SBA}-16$ (denoted as $\mathrm{Pt} / \mathrm{CZB} / \mathrm{SBA}-16$ hereafter) catalyst.

\section{2 Characterization}

The composition of the Pt/CZB/SBA-16 catalyst was confirmed to be in good agreement with the stoichiometric ratio of the starting materials using X-ray fluorescence analysis (XRF, Rigaku Supermini200). X-ray powder diffraction and small angle X-ray scattering (XRD and SAXS respectively, Rigaku SmartLab) patterns were measured in the $2 \theta$ range of $10^{\circ}-70^{\circ}$ and $0.06^{\circ}-2.0^{\circ}$, respectively. The $\mathrm{Pt}$ particle size after the heat treatment at $500{ }^{\circ} \mathrm{C}$ for $4 \mathrm{~h}$ in air was determined using the following Scherrer equation:

$$
D=\frac{k \cdot \lambda}{\beta \cdot \cos \theta}
$$

where $D$ is the mean size of the crystalline domains; $k$ is a dimensionless shape factor which is equal to $0.9 ; \lambda$ is the $\mathrm{X}$-ray wavelength which is $0.154 \mathrm{~nm}$ for $\mathrm{Cu} \mathrm{K \alpha}$; $\beta$ is the full width at half maximum (FWHM); and $\theta$ is the Bragg angle. The Brunauer-Emmett-Teller (BET) surface area and the pore size distribution were measured at $-196{ }^{\circ} \mathrm{C}$ (Micromeritics Tristar 3000) using $\mathrm{N}_{2}$ adsorption. Scanning electron microscopy (SEM, Shimadzu SS-550) and transmission electron microscopy (TEM, Hitachi H-9000NAR) were conducted to observe the morphology and size of the particles.

The oxidation reaction of 1,4-dioxane was conducted in the air atmosphere in batch mode using a mechanically stirred $300 \mathrm{~cm}^{3}$ three-necked flask. Prior to the reaction, an aqueous solution of $100 \mathrm{ppm}$ 1,4-dioxane $\left(10 \mathrm{~cm}^{3}\right)$ was poured into the flask, and Pt/CZB/SBA-16, CZB/SBA-16, Pt/SBA-16 or SBA-16 $(0.3 \mathrm{~g})$ was loaded. The reactor was then heated to reflux in an oil bath at a stable operational temperature in the range of $40-80{ }^{\circ} \mathrm{C}$. After the $4 \mathrm{~h}$ reaction, the catalyst was separated by centrifugation, and the supernatant liquid was analyzed using gas chromatograph mass spectrometry (GCMS, Shimadzu GCMS-QP2010 Plus) to evaluate the rate of decrease in 1,4-dioxane. In addition, time course of catalytic activity for $\mathrm{Pt} / \mathrm{CZB} / \mathrm{SBA}-16$ was also measured at $80{ }^{\circ} \mathrm{C}$ for $2 \mathrm{~h}, 4 \mathrm{~h}$ and $6 \mathrm{~h}$ using an aqueous solution of 100 ppm 1,4-dioxane. 


\section{Results and discussion}

The SBA-16 support has a large surface area of $927 \mathrm{~m}^{2} / \mathrm{g}$, but it significantly decreases to $475 \mathrm{~m}^{2} / \mathrm{g}$ after introduction of $\mathrm{Pt}$ and $\mathrm{CZB}$ into the mesopores of SBA-16. Figure 1 shows the $\mathrm{N}_{2}$ adsorption-desorption isotherms of SBA-16 and Pt/CZB/SBA-16. The pore size distribution profiles calculated from the $\mathrm{N}_{2}$ adsorption isotherms using the International Union of Pure and Applied Chemistry (IUPAC) and the Barrett-Joyner-Halenda (BJH) analysis [16] are also depicted in the insets. According to BrunauerDerning-Deming-Teller (BDDT) classifications, the pattern of these isotherms is classified to the type IV, which is typical for materials with mesopore structures. The average pore size of the $\mathrm{Pt} / \mathrm{CZB} / \mathrm{SBA}-16$ catalyst is $9.0 \mathrm{~nm}$, which is smaller than that of SBA-16 $(9.4 \mathrm{~nm})$. The BJH analysis was carried out again to identify whether the difference was led by experimental error, but a reproducible result was obtained. These results also suggest that the pores are filled with $\mathrm{Pt}$ and/or CZB particles.

Figure 2 depicts the XRD pattern of the Pt/CZB/SBA-16 catalyst. The detectable diffraction peaks in the pattern are well indexed to those of $\mathrm{Pt}$, CZB and SBA-16. The six broad peaks at $2 \theta=28.4^{\circ}$,

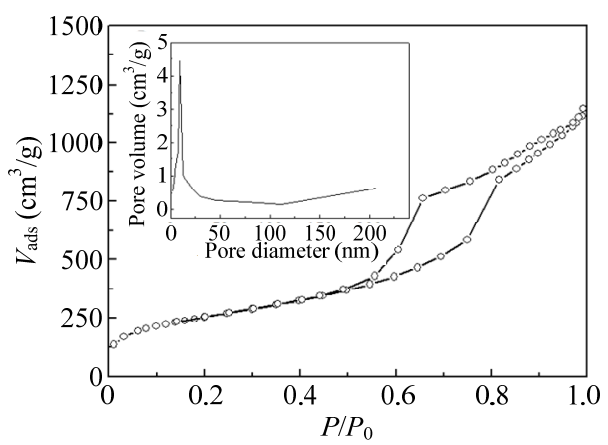

(a)

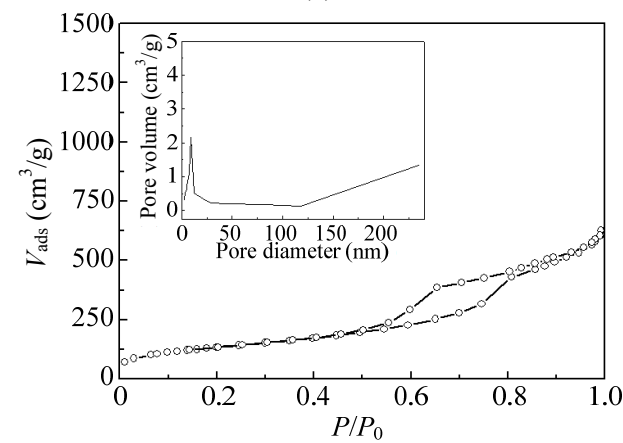

(b)

Fig. $1 \quad \mathrm{~N}_{2}$ adsorption-desorption isotherms of (a) SBA-16 and (b) Pt/CZB/SBA-16. The BJH pore size distribution profiles are shown in the insets.

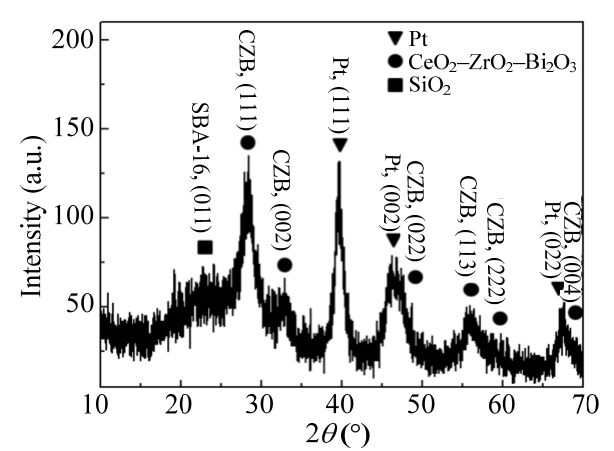

Fig. 2 XRD pattern of the Pt/CZB/SBA-16 catalyst.

$32.8^{\circ}, 46.7^{\circ}, 56.3^{\circ}, 58.5^{\circ}$ and $69.7^{\circ}$ are assigned to (111), (002), (022), (113), (222) and (004) reflections of cubic fluorite-type structure respectively, while three peaks observed at $2 \theta=39.6^{\circ}, 46.0^{\circ}$ and $67.5^{\circ}$ correspond to those of platinum. The diffraction peak at $2 \theta=22.7^{\circ}$ is very broad due to the low crystallinity of the SBA-16 crystallites. The Pt particle size is calculated to be $8.9 \mathrm{~nm}$ from the Scherrer equation using the FWHM and angular position of the (111) peak.

Figure 3 shows the SAXS patterns of SBA- 16 and $\mathrm{Pt} / \mathrm{CZB} / \mathrm{SBA}-16$. The diffraction peak at $2 \theta=0.6^{\circ}$ in Fig. 3(a) elucidates that mesopores of SBA-16 are successfully synthesized. After the loading of Pt and $\mathrm{CZB}$, the intensity of the diffraction peak is significantly decreased in comparison with that for as-prepared SBA-16, and the diffraction angle shifts to higher direction indicating the decrease in the pore size of SBA-16. These results indicate that the Pt and/or CZB particles are loaded in the pores of SBA-16.

Figure 4 shows an SEM image of the SBA-16 support. The particle size of the SBA-16 support is approximately $2 \mu \mathrm{m}$. TEM images of the SBA-16 support and the Pt/CZB/SBA-16 catalyst are displayed in Fig. 5. The synthesized SBA-16 support possesses a



Fig. 3 SAXS patterns of (a) SBA-16 and (b) $\mathrm{Pt} / \mathrm{CZB} / \mathrm{SBA}-16$. 


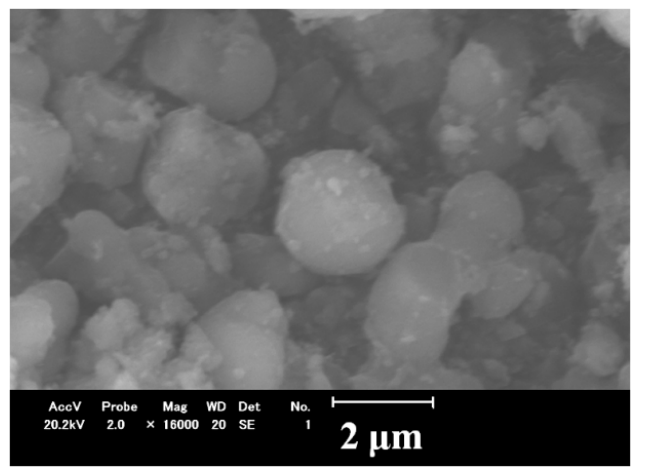

Fig. 4 SEM image of the SBA-16 support.
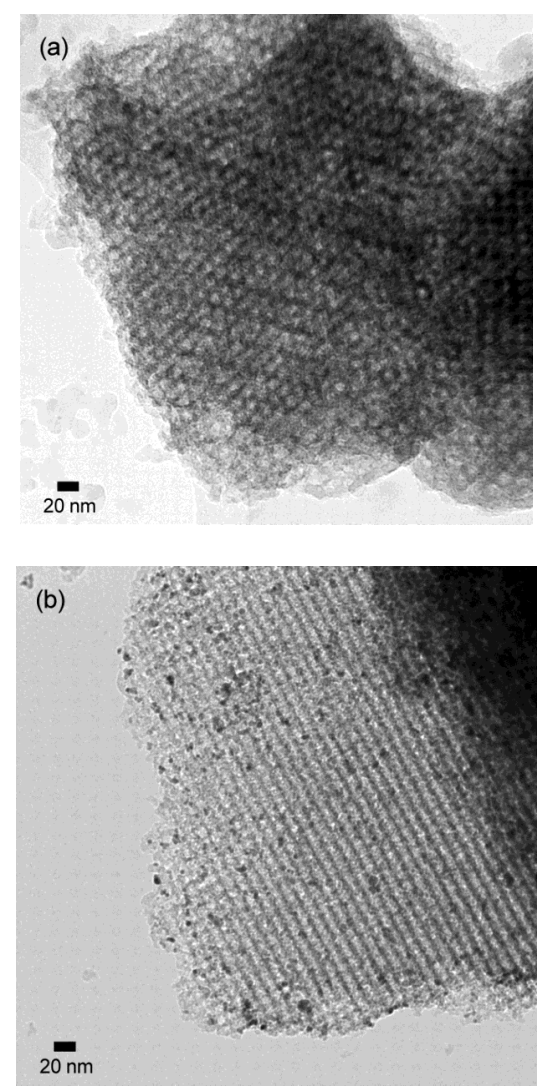

Fig. 5 TEM images of (a) SBA-16 support and (b) $\mathrm{Pt} / \mathrm{CZB} / \mathrm{SBA}-16$ catalyst.

regular arrangement of mesopores, and the pore diameter is approximately $10 \mathrm{~nm}$ as shown in Fig. 5(a). After the introduction of the $\mathrm{Pt}$ and CZB particles, these particles are observed in Fig. 5(b) as dark spots in and on the SBA-16 support, although it is difficult to distinguish between $\mathrm{Pt}$ and $\mathrm{CeO}_{2}-\mathrm{ZrO}_{2}-\mathrm{Bi}_{2} \mathrm{O}_{3}$. These results are in agreement with the results of the SAXS measurement that $\mathrm{Pt}$ and $\mathrm{CZB}$ particles are well dispersed into the mesopores of SBA-16, as well as those of the $\mathrm{BJH}$ pore size distribution described above.

Finally, the results on the catalytic liquid phase oxidation of 1,4-dioxane using SBA-16, CZB/SBA-16, Pt/SBA-16 and Pt/CZB/SBA-16 are tabulated in Tables 1 and 2. The supernatant liquid after the reaction was analyzed using GCMS. As a result, any by-products are not detected: only 1,4-dioxane is detected and its concentration is smaller than that before the reaction. Accordingly, it is considered that carbon dioxide and water are generated by oxidation of 1,4-dioxane. The residual percentage of 1,4-dioxane in Table 1 was calculated according to the following equation:

$$
\begin{aligned}
& \text { Molar concentration of 1,4-dioxane } \\
& \text { after the reaction } \\
& \text { Molar concentration of 1,4-dioxane } \times 100 \% \\
& \text { before the reaction }
\end{aligned}
$$

The rate of decrease in 1,4-dioxane after the oxidation reaction summarized in Table 2 was estimated by deduction of the residual percentage of 1,4-dioxane in the presence of CZB/SBA-16, Pt/SBA-16 and $\mathrm{Pt} / \mathrm{CZB} / \mathrm{SBA}-16$ from that obtained in the blank test performed with SBA-16 in Table 1. In the blank test using SBA-16, effects of both vaporization and adsorption on the SBA-16 support are included. Accordingly, the rate of decrease in 1,4-dioxane in Table 2 shows the result just caused by oxidation.

As seen in Table 2, the oxidation catalysis of CZB/SBA-16, Pt/SBA-16 and $\mathrm{Pt} / \mathrm{CZB} / \mathrm{SBA}-16$ is obviously recognized and the rate of decrease in 1,4-dioxane increases with a rise in the reaction temperature. Among the samples tested, Pt/CZB/SBA16 shows the highest oxidation activity. These results demonstrate that the insertion of both $\mathrm{Pt}$ and $\mathrm{CZB}$ particles into the mesopores of the SBA-16 support enables high catalytic activity. In addition, time course of catalytic activity for $\mathrm{Pt} / \mathrm{CZB} / \mathrm{SBA}-16$ was also measured at $80{ }^{\circ} \mathrm{C}$ for $2 \mathrm{~h}, 4 \mathrm{~h}$ and $6 \mathrm{~h}$ (Table 3). It clarifies that the catalytic reaction proceeds

Table 1 Residual percentage of 1,4-dioxane after the $4 \mathrm{~h}$ reaction in the air atmosphere

\begin{tabular}{ccccc}
\hline Reaction & \multicolumn{4}{c}{ Residual percentage of 1,4-dioxane (\%) } \\
\cline { 2 - 5 } temperature $\left({ }^{\circ} \mathrm{C}\right)$ & SBA-16 & CZB/SBA-16 & Pt/SBA-16 & Pt/CZB/SBA-16 \\
\hline 40 & 74 & 67 & 65 & 60 \\
60 & 79 & 68 & 64 & 49 \\
80 & 75 & 53 & 50 & 41 \\
\hline
\end{tabular}

Table 2 Rate of decrease in 1,4-dioxane after the $4 \mathrm{~h}$ reaction in the air atmosphere

\begin{tabular}{cccc}
\hline Reaction & \multicolumn{3}{c}{ Rate of decrease in 1,4-dioxane (\%) } \\
\cline { 2 - 4 } temperature $\left({ }^{\circ} \mathrm{C}\right)$ & $\mathrm{CZB} / \mathrm{SBA}-16$ & $\mathrm{Pt} / \mathrm{SBA}-16$ & $\mathrm{Pt} / \mathrm{CZB} / \mathrm{SBA}-16$ \\
\hline 40 & 7 & 9 & 14 \\
60 & 11 & 15 & 30 \\
80 & 22 & 25 & 34 \\
\hline
\end{tabular}


Table 3 Rate of decrease in 1,4-dioxane after the reaction at $80{ }^{\circ} \mathrm{C}$ for $2 \mathrm{~h}, 4 \mathrm{~h}$ and $6 \mathrm{~h}$

\begin{tabular}{cccc}
\hline \multirow{2}{*}{$\begin{array}{c}\text { Reaction } \\
\text { time (h) }\end{array}$} & \multicolumn{2}{c}{$\begin{array}{c}\text { Residual percentage of } \\
\text { 1,4-dioxane (\%) }\end{array}$} & \multirow{2}{*}{$\begin{array}{c}\text { Rate of decrease } \\
\text { in 1,4-dioxane } \\
(\%)\end{array}$} \\
\cline { 2 - 3 } & SBA-16 & Pt/CZB/SBA-16 & 13 \\
\hline 2 & 73 & 60 & 34 \\
4 & 75 & 41 & 38 \\
\hline
\end{tabular}

continuously. Although the maximum degradation rate of decrease in 1,4-dioxane is $38 \%$ at $80{ }^{\circ} \mathrm{C}$ using $\mathrm{Pt} / \mathrm{CZB} / \mathrm{SBA}-16$ at this time, the purification ability will be increased by the improvement of the oxygen supplying ability of the promoter by using $\mathrm{CeO}_{2}-\mathrm{ZrO}_{2}-\mathrm{SnO}_{2}$ solid solutions [17] in the near future work.

\section{Conclusions}

A novel oxidation catalyst composed of $\mathrm{Pt}$, $\mathrm{CeO}_{2}-\mathrm{ZrO}_{2}-\mathrm{Bi}_{2} \mathrm{O}_{3}$ and SBA-16 was prepared for liquid phase oxidation of 1,4-dioxane in wastewater. The oxidation reaction was progressed effectively by the loading of the $\mathrm{Pt}$ and $\mathrm{CeO}_{2}-\mathrm{ZrO}_{2}-\mathrm{Bi}_{2} \mathrm{O}_{3}$ particles into the mesopores of SBA-16. The catalytic activity was increased with increasing the reaction temperature and the catalytic reaction proceeded continuously with time course. As a result, the rate of decrease in 1,4-dioxane reached $38 \%$ after the reaction at $80{ }^{\circ} \mathrm{C}$ for $6 \mathrm{~h}$ in the air atmosphere.

Open Access: This article is distributed under the terms of the Creative Commons Attribution License which permits any use, distribution, and reproduction in any medium, provided the original author(s) and the source are credited.

\section{References}

[1] Budavari S, O'Neil MJ, Smith A, et al. The Merck Index, 11th edn. Rahway, NJ (USA): Merck \& Co., Inc., 1989.

[2] Chitra S, Paramasivan K, Cheralathan $\mathrm{M}$, et al. Degradation of 1,4-dioxane using advanced oxidation processes. Environ Sci Pollut R 2012, 19: 871-878.

[3] Adams CD, Scanlan PA, Secrist ND. Oxidation and biodegradability enhancement of 1,4-dioxane using hydrogen peroxide and ozone. Environ Sci Technol 1994, 28: $1812-1818$.

[4] Fan W, Kubota Y, Tatsumi T. Oxidation of 1,4-dioxane over Ti-MWW in the presence of $\mathrm{H}_{2} \mathrm{O}_{2}$. ChemSusChem 2008, 1: 175-178.

[5] Yamazaki K, Ohno $\mathrm{H}$, Asakura $\mathrm{M}$, et al. Two-year toxicological and carcinogenesis studies of 1,4-dioxane in F344 rats and BDF1 mice-drinking studies. In Proceedings: Second Asia-Pacific Symposium on Environmental and Occupational Health 22-24 July, 1993: Kobe. Sumino K, Sato S, Shinkokai NG, Eds. Kobe University, 1994: 193-198.

[6] Ministry of the Environment, Government of Japan. Environmental quality standards for water pollution. Available at https://www.env.go.jp/en/water/wq/wp.pdf.

[7] Klečka GM, Gonsior SJ. Removal of 1,4-dioxane from wastewater. J Hazard Mater 1986, 12: 161-168.

[8] Makino R, Gamo M, Sato N, et al. Removal rate of 1,4-dioxane in a sewage treatment plant. J Jpn Soc Water Environ 2005, 28: 211-215.

[9] Aizawa T. Contamination of drinking water sources with novel pollutants. J Environ Conserv Engineering 2001, 30: 592-597.

[10] Zhao D, Huo Q, Feng J, et al. Nonionic triblock and star diblock copolymer and oligomeric surfactant syntheses of highly ordered, hydrothermally stable, mesoporous silica structures. J Am Chem Soc 1998, 120: 6024-6036.

[11] Masui T, Minami K, Koyabu K, et al. Synthesis and characterization of new promoters based on $\mathrm{CeO}_{2}-\mathrm{ZrO}_{2}-\mathrm{Bi}_{2} \mathrm{O}_{3}$ for automotive exhaust catalysts. Catal Today 2006, 117: 187-192.

[12] Imanaka N, Masui $\mathrm{T}$, Koyabu $\mathrm{K}$, et al. Significant low-temperature redox activity of $\mathrm{Ce}_{0.64} \mathrm{Zr}_{0.16} \mathrm{Bi}_{0.20} \mathrm{O}_{1.90}$ supported on $\gamma-\mathrm{Al}_{2} \mathrm{O}_{3}$. Adv Mater 2007, 19: 1608-1611.

[13] Imanaka N, Masui T, Yasuda K. Environmental catalysts for complete oxidation of volatile organic compounds and methane. Chem Lett 2011, 40: 780-785.

[14] Yotou H, Okamoto T, Ito $\mathrm{M}$, et al. Novel method for insertion of $\mathrm{Pt} / \mathrm{CeZrO}_{2}$ nanoparticles into mesoporous SBA-16 using hydrothermal treatment. Appl Catal A: Gen 2013, 458: 137-144.

[15] Masui T, Imadzu H, Matsuyama N, et al. Total oxidation of toluene on $\mathrm{Pt} / \mathrm{CeO}_{2}-\mathrm{ZrO}_{2}-\mathrm{Bi}_{2} \mathrm{O}_{3} / \gamma-\mathrm{Al}_{2} \mathrm{O}_{3}$ catalysts prepared in the presence of polyvinyl pyrrolidone. $J$ Hazard Mater 2010, 176: 1106-1109.

[16] Barrett EP, Joyner LG, Halenda PP. The determination of pore volume and area distributions in porous substances. I. Computations from nitrogen isotherms. $\mathrm{J} \mathrm{Am} \mathrm{Chem} \mathrm{Soc}$ 1951, 73: 373-380.

[17] Yasuda K, Yoshimura A, Katsuma A, et al. Low-temperature complete combustion of volatile organic compounds over novel $\mathrm{Pt} / \mathrm{CeO}_{2}-\mathrm{ZrO}_{2}-\mathrm{SnO}_{2} / \gamma-\mathrm{Al}_{2} \mathrm{O}_{3}$ catalysts. Bull Chem Soc Jpn 2012, 85: 522-526. 